\title{
Responses of trifoliate orange (Poncirus trifoliata (L.) Raf.) to continuously and gradually increasing $\mathrm{NaCl}$ concentration
}

\author{
Christos Chatzissavvidis ${ }^{1 *}$, Chrysovalantou Antonopoulou ${ }^{2}$, \\ IOANNIS THERIOS $^{2}$, KORTESSA DIMASSI ${ }^{2}$ \\ ${ }^{1}$ Laboratory of Pomology, Department of Agricultural Development, \\ Democritus University of Thrace, Pantazidou 193, 68200 Orestiada, Greece \\ ${ }^{2}$ Laboratory of Pomology, School of Agriculture, Aristotle University, \\ 54124 Thessaloniki, Greece
}

\begin{abstract}
The effect of continuous or gradual stress due to $\mathrm{NaCl}$ on in vitro growth, proline and sugar accumulation and nutrient acquisition of trifoliate orange (Poncirus trifoliata (L.) Raf.) explants was studied. Apical shoot tips obtained from previous subculture were transferred to a Murashige and Skoog nutrient medium for proliferation and were exposed to continuous or gradual salinity stress for 42 days. The salt used to induce salinity was $\mathrm{NaCl}$ added in six concentrations: 0, 50, 100, 150, 200 and $300 \mathrm{mM}$. Gradual salinization was achieved by transferring the explants sequentially every week to the above mentioned $\mathrm{NaCl}$ concentrations. Most salt treatments had a negative effect on the growth parameters of explants. Sodium concentration of explants increased in all $\mathrm{NaCl}$ treatments compared to control and it was higher in the treatments with gradual exposure to salinity. Potassium concentration was reduced, mostly in the treatments with continuous exposure. Calcium and $\mathrm{Mg}$ concentrations increased in all saline treatments. In general, the high salinity level in the substrate enhanced the proline and sugar concentrations of the studied explants. In conclusion, salinity had significant impacts on the growth and chemical status of $P$. trifoliata.
\end{abstract}

Keywords: Carbohydrates, micropropagation, Poncirus trifoliata, proline, salinity stress

\section{Introduction}

Citrus is one of the most economically important crops worldwide. However, in arid and semi-arid regions drought and saline irrigation water are a common problem and a major consideration in citrus production (FERGUSON and GRATTAN 2005). The damage to plants exposed to salinity has been attributed to ion toxicity, nutrient imbalance, osmotic and

* Corresponding author, e-mail: cchatz@agro.duth.gr

Copyright ${ }^{\circledR} 2014$ by Acta Botanica Croatica, the Faculty of Science, University of Zagreb. All rights reserved. 
oxidative stress (GratTAN and Grieve 1998, Zhu 2001). Compared with other crops, Citrus and Poncirus are among the most sensitive to soil salinity, although the ability of citrus trees to tolerate salinity varies among species and depends on the rootstock. For orange, the values of electrical conductivity of the soil solution that correspond to a $100 \%, 50 \%$, or zero yield potential are 1.7, 4.8 and $8.0 \mathrm{dS} \mathrm{m}^{-1}$, respectively (MAAS 1984).

The genera Citrus and Poncirus are commonly used rootstocks and ornamental species worldwide. Field screening in saline sites to select salt tolerant genotypes of citrus rootstocks is complicated because of differential ontogenic reactions of the plant to salinity and a large genotype in combination with environment interaction. In vitro tissue culture is a simple technique that offers a suitable alternative for the study of physiological mechanisms of tolerance to salinity, since it provides relatively fast responses, needs a short testing time and a controlled environment, especially in tree species that have long reproductive cycles (Perez-Tornero et al. 2009).

The aim of this experiment was to examine nutritional, physiological and growth responses of in vitro cultivated trifoliate orange (Poncirus trifoliata (L.) Raf.) to continuously and gradually increasing external $\mathrm{NaCl}$ concentration.

\section{Materials and methods}

Apical shoot tips (length approximately $20 \mathrm{~mm}$ ) of trifoliate orange (Poncirus trifoliata (L.) Raf.) obtained from previous subculture, were transferred to a Murashige and Skoog nutrient medium (MurASHIGE and SKOOG 1962) for proliferation and were exposed to continuous or gradual salinity stress in vitro. The salt used to induce salinity was $\mathrm{NaCl}$ added in six concentrations: 0 (control), 50, 100, 150, 200 and $300 \mathrm{mM}$ (or 0, 3, 6, 9, 12 and $16 \mathrm{~g} \mathrm{~L}^{-1}$, respectively). Gradual salinization was achieved by transferring the explants sequentially every week to the above mentioned $\mathrm{NaCl}$ concentrations. All media contained $2 \mathrm{mg} \mathrm{L}^{-1} \mathrm{BA}$ (6-benzyladenine), $0.1 \mathrm{mg} \mathrm{L}^{-1} \mathrm{IBA}$ (3-indolebutyric acid), $30 \mathrm{~g} \mathrm{~L}^{-1}$ sucrose and $6 \mathrm{~g} \mathrm{~L}^{-1}$ agar (Oxoid No3). The $\mathrm{pH}$ of the medium was adjusted to 5.8 prior to autoclaving at $121{ }^{\circ} \mathrm{C}$ for 20 minutes. Cultures were incubated at $25 \pm 2{ }^{\circ} \mathrm{C}$ under cool white fluorescent tube lamps $\left(90 \mu \mathrm{mol} \mathrm{m}^{-2} \mathrm{~s}^{-1}\right)$, with a 16-hours photoperiod, for six weeks. Each treatment consisted of 15 replicates (tubes). For the explants grown under continuous salt stress, growth characteristics (shoot number and length, fresh and dry matter weight) were recorded at the end of the experiment, while for the explants exposed to gradual salinity stress, growth parameters were recorded at each $\mathrm{NaCl}$ treatment after each transfer. At the same time, samples of explants were analyzed for proline and carbohydrates according to KHAN et al. (2000). Furthermore, after growth assessment, explants were dried at $75^{\circ} \mathrm{C}$ for 48 hours, ground to a fine powder and ashed at 500-550 ${ }^{\circ} \mathrm{C}$. Subsequently, the shoot samples were analyzed for concentration of $\mathrm{K}, \mathrm{Ca}, \mathrm{Mg}, \mathrm{Mn}, \mathrm{Zn}$ and $\mathrm{Na}$ ions by atomic absorption spectroscopy (Perkin-Elmer 2380) and for concentration of $\mathrm{Cl}$ ions by titration with $\mathrm{AgNO}_{3}$. The experimental layout was completely randomized and the experiment was repeated twice. The reported data are the means of the two experiments. Means were compared using the Duncan multiple range test for $\mathrm{p} \leq 0.05$.

\section{Results and discussion}

Some explants treated continuously with $300 \mathrm{mM} \mathrm{NaCl}$ showed signs of chlorosis and/or wilting (data not shown). These salt injuries could be due to accumulation of $\mathrm{Na}$ or $\mathrm{Cl}$ 
(or both) resulting in excessive levels of transpiring leaves, building up rapidly in the cytoplasm and inhibiting enzyme activity, or in the cell walls, altering their functioning (FLOWERS and YEO 1986). It is well established that salinity stress is followed by chlorophyll degradation that leads to a chlorotic appearance in explants. High concentrations of $\mathrm{NaCl}$ applied under in vitro conditions reduced the chlorophyll content in Citrus (PEREZ-TORNERO et al. 2009) and other woody species (CHATZISSAVvidis et al. 2008). Similarly, GHALEB et al. (2010) experimenting with sour orange cultivated under in vitro conditions recorded complete leaf damage at $300 \mathrm{mM} \mathrm{NaCl}$.

In all $\mathrm{NaCl}$ treatments, a decreased number of shoots per explants was observed (Tab. 1). Similarly, in explants of Citrus macrophylla a significant decrease in the shoot number was observed at $30 \mathrm{mM} \mathrm{NaCl}$ (PEREZ-TORNERO et al. 2009). Also, it was reported that continuous or gradual exposure to high $\mathrm{NaCl}$ in nutrient medium led to a reduced number of shoots in sour orange (SHIYAB et al. 2003). The length of shoots produced at and above $150 \mathrm{mM} \mathrm{NaCl}$ was found to be significantly decreased in continuous maintenance treatments and increased in the gradual transfer treatments, except for the treatment with $300 \mathrm{mM} \mathrm{NaCl}$ (Tab. 1). Likewise, SHIYAB et al. (2003) observed that shoot length of sour orange explants was negatively affected by continuous and gradual exposure at a salinity level of $150 \mathrm{mM} \mathrm{NaCl}$ or higher. Similarly, bitter almond (Prunus dulcis (Miller) D. Webb.) explants showed decreased shoot length when cultured on a substrate with high $\mathrm{NaCl}$ content (SHIBLI et al. 2003). The weight of fresh and dry matter of shoots was decreased by $\mathrm{NaCl}$ treatments (Tab. 1). The fact that the explants gradually exposed to $150-300 \mathrm{mM} \mathrm{NaCl}$ had higher dry matter weight than those exposed to $50-100 \mathrm{mM}$ seems to be an unexpected result. A possible explanation is that the explants grown under high salinity benefit from gradual exposure (as compared to continuous one) and develop a mechanism that directs salt ions to build up in the apoplast of cells, or be isolated within the vacuole. In any case, further research on gradual and continuous exposure of plants to salinity would elucidate this point. In agreement to these results, SHIYAB et al. (2003), experimenting with sour orange cultured under $\mathrm{NaCl}$ stress, observed a negative effect on explant weight, mainly in continuous exposure treatments. The inclusion of $\mathrm{NaCl}$ in the nutrient medium also led to a decrease in dry

Tab. 1. Effect of continuously (C) and gradually $(\mathrm{G})$ increased $\mathrm{NaCl}$ levels on certain growth parameters, total sugar and proline concentrations of trifoliate orange explants. Mean values followed by different letters in each column are statistically different (Duncan's multiple range test, $\mathrm{p} \leq 0.05$ ).

\begin{tabular}{|c|c|c|c|c|c|c|c|c|c|c|c|c|}
\hline \multirow{3}{*}{ 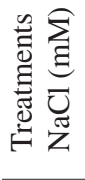 } & \multirow{2}{*}{\multicolumn{2}{|c|}{$\begin{array}{l}\text { Number } \\
\text { of } \\
\text { shoots }\end{array}$}} & \multirow{2}{*}{\multicolumn{2}{|c|}{$\begin{array}{l}\text { Length of } \\
\text { shoots } \\
(\mathrm{cm})\end{array}$}} & \multicolumn{4}{|c|}{$\begin{array}{l}\text { Shoot weight } \\
\text { (mg) }\end{array}$} & \multirow{2}{*}{\multicolumn{2}{|c|}{$\begin{array}{c}\text { Total } \\
\text { sugars } \\
\left(\mu \mathrm{mol} \mathrm{g}{ }^{-1} \text { f.w. }\right) \\
\end{array}$}} & \multirow{2}{*}{\multicolumn{2}{|c|}{$\begin{array}{c}\text { Proline } \\
\left(\mu \mathrm{mol} \mathrm{g}{ }^{-1} \text { f.w. }\right)\end{array}$}} \\
\hline & & & & & & & dry $n$ & natter & & & & \\
\hline & $\mathrm{C}$ & G & $\mathrm{C}$ & G & $\mathrm{C}$ & G & C & G & C & G & C & G \\
\hline 0 & $8.1^{\mathrm{a}}$ & $8.1^{\mathrm{a}}$ & $0.86^{\mathrm{ab}}$ & $0.86^{\mathrm{d}}$ & $580^{\mathrm{a}}$ & $580^{\mathrm{a}}$ & $93^{\mathrm{a}}$ & $93^{\mathrm{a}}$ & $27.03^{b}$ & $27.03^{c}$ & $37.13^{b}$ & $37.13^{b}$ \\
\hline 50 & $4.3^{\mathrm{b}}$ & $3.9^{\text {cd }}$ & $0.99^{\mathrm{a}}$ & $0.94^{\mathrm{c}}$ & $432^{\mathrm{b}}$ & $262^{\mathrm{e}}$ & $75^{\mathrm{b}}$ & $59^{\mathrm{d}}$ & $35.58^{\mathrm{ab}}$ & $36.47^{\mathrm{c}}$ & $46.80^{\mathrm{ab}}$ & $38.45^{\mathrm{b}}$ \\
\hline 100 & $2.1^{\mathrm{cd}}$ & $2.7^{\mathrm{cd}}$ & $0.59^{b c}$ & $0.34^{\mathrm{f}}$ & $237^{c}$ & $187^{\mathrm{f}}$ & $62^{\mathrm{bc}}$ & $51^{\mathrm{e}}$ & $51.86^{\mathrm{a}}$ & $41.87^{\mathrm{bc}}$ & $54.51^{\mathrm{a}}$ & $38.79^{\mathrm{ab}}$ \\
\hline 150 & $2.9^{\mathrm{bc}}$ & $5.1^{\mathrm{bc}}$ & $0.26^{\mathrm{cd}}$ & $1.09^{\mathrm{a}}$ & $206^{\mathrm{c}}$ & $409^{\mathrm{b}}$ & $55^{\mathrm{c}}$ & $81^{b}$ & $40.60^{\mathrm{ab}}$ & $41.24^{\mathrm{bc}}$ & $49.95^{\mathrm{ab}}$ & $38.60^{\mathrm{ab}}$ \\
\hline 200 & $1.7^{\mathrm{cd}}$ & $5.7^{\mathrm{b}}$ & $0.28^{\mathrm{cd}}$ & $1.03^{\mathrm{b}}$ & $154^{\mathrm{c}}$ & $400^{c}$ & $48^{c}$ & $75^{\mathrm{bc}}$ & $46.38^{\mathrm{a}}$ & $65.48^{\mathrm{a}}$ & $55.85^{\mathrm{a}}$ & $49.30^{\mathrm{a}}$ \\
\hline 300 & $0.7^{\mathrm{d}}$ & $3.9^{\mathrm{cd}}$ & $0.11^{\mathrm{d}}$ & $0.68^{\mathrm{e}}$ & $141^{\mathrm{c}}$ & $313^{d}$ & $52^{\mathrm{c}}$ & $69^{c}$ & $40.63^{\mathrm{ab}}$ & $50.73^{\mathrm{ab}}$ & $56.40^{\mathrm{a}}$ & $42.74^{\mathrm{a}}$ \\
\hline
\end{tabular}


weight of bitter almond explants (SHIBLI et al. 2003). The reduced vegetative growth of the $\mathrm{NaCl}$ treated explants may partly be attributed to impairment of their photosynthetic efficiency. Photosynthesis, together with cell growth, is among the primary processes to be affected by salinity (MunNs et al. 2006). Moreover, since under in vitro conditions relative humidity is very high, the toxic effects of salinity are more likely to be due to ion toxicity rather than to water stress (MiLLs et al. 2001).

Sodium concentration in the trifoliate orange explants increased significantly in all $\mathrm{NaCl}$ treatments compared to control and, specifically, it was higher in the treatments with gradual exposure to salinity. In the treatments above $150 \mathrm{mM} \mathrm{NaCl}$ (continuous exposure) and those above $50 \mathrm{mM} \mathrm{NaCl}$ (gradual exposure), $\mathrm{Na}$ concentration reached excessive or toxic levels $(>0.25 \%)$ for citrus leaves. This pattern, the result of increasing $\mathrm{NaCl}$ in the medium, is a common and expected response and has been reported for many citrus species (Dionisio and Antonit 1997, Shiyab et al. 2003, Perez-Tornero et al. 2009, Ghaleb et al. 2010). Moreover, it is well documented that tissue concentrations of $\mathrm{Cl}$ in Citrus increase in response to $\mathrm{NaCl}$ treatments (Dionisio and ANTONII 1997, PEREZ-Tornero et al. 2009, GHALEB et al. 2010). The concentration of chloride in explants was several times higher than that of $\mathrm{Na}$, and a similar response was also observed for jojoba (Simmondsia chinensis (Link) Schneid) explants under high salinity conditions (Roussos et al. 2007). Interestingly, Cl increased more than $\mathrm{Na} ; \mathrm{Cl}$ was $578 \%$ higher at $300 \mathrm{mM} \mathrm{NaCl}$ with respect to $0 \mathrm{mM} \mathrm{NaCl}$, whereas Na was only $24.5 \%$ higher (Tab. 2). According to PEREZ-Tornero et al. (2009), these results suggest that the important deleterious effects in the Poncirus trifoliata explants grown in vitro at increasing $\mathrm{NaCl}$ concentration could be due to toxic intracellular levels of saline ions, mainly $\mathrm{Cl}$. Since, in general, $\mathrm{Cl}$ concentration in orange plants above $1 \%$ may be toxic causing leaf burn and defoliation (Koo et al. 1984), $\mathrm{Cl}$ concentrations found in the explants treated with $\mathrm{NaCl}$ in the present experiment are considered to be high.

As regards $\mathrm{K}$ concentration, it was reduced in all saline treatments compared to control (Tab. 2). Specifically, in high $\mathrm{NaCl}$ treatments, the decline of $\mathrm{K}$ concentration was higher in the treatments with continuous exposure. A decline of $\mathrm{K}^{+}$concentration in Citrus explants caused by the inclusion of $\mathrm{NaCl}$ into the nutrient medium has also been reported by other researchers (Dionisio and Antoni 1997, ShiYAB et al. 2003, PEREZ-Tornero et al. 2009, GHALEB et al. 2010). What is more, this reduction was less in gradually shocked cultures, as was also found by SHIYAB et al. (2003) for sour orange. The decrease of K concentrations of

Tab. 2. Effect of continuously (C) and gradually (G) increased $\mathrm{NaCl}$ levels on $\mathrm{Na}, \mathrm{Cl}, \mathrm{K}, \mathrm{Ca}$ and $\mathrm{Mg}$ concentrations (\% d.w.) of trifoliate orange explants. Mean values followed by different letters in each column are statistically different (Duncan's multiple range test, $\mathrm{p} \leq 0.05$ ).

\begin{tabular}{|c|c|c|c|c|c|c|c|c|c|c|}
\hline \multirow{2}{*}{$\begin{array}{l}\text { Treatments } \\
\mathrm{NaCl}(\mathrm{mM})\end{array}$} & \multicolumn{2}{|c|}{$\mathrm{Na}$} & \multicolumn{2}{|c|}{$\mathrm{Cl}$} & \multicolumn{2}{|c|}{ K } & \multicolumn{2}{|c|}{$\mathrm{Ca}$} & \multicolumn{2}{|c|}{$\mathrm{Mg}$} \\
\hline & $\mathrm{C}$ & $\mathrm{G}$ & $\mathrm{C}$ & G & $\mathrm{C}$ & $\mathrm{G}$ & $\mathrm{C}$ & G & $\mathrm{C}$ & G \\
\hline 0 & $0.220^{\mathrm{f}}$ & $0.220^{\mathrm{e}}$ & $0.84^{\mathrm{f}}$ & $0.84^{\mathrm{e}}$ & $1.69^{\mathrm{a}}$ & $1.69^{\mathrm{a}}$ & $0.91^{\mathrm{e}}$ & $0.91^{\mathrm{d}}$ & $0.15^{\mathrm{e}}$ & $0.15^{\mathrm{e}}$ \\
\hline 50 & $0.235^{\mathrm{c}}$ & $0.247^{\mathrm{d}}$ & $2.56^{\mathrm{e}}$ & $2.50^{\mathrm{d}}$ & $1.53^{\mathrm{b}}$ & $1.27^{\mathrm{c}}$ & $1.04^{\mathrm{d}}$ & $1.76^{\mathrm{a}}$ & $0.18^{\mathrm{d}}$ & $0.27^{\mathrm{a}}$ \\
\hline 100 & $0.228^{\mathrm{e}}$ & $0.252^{\mathrm{c}}$ & $2.64^{\mathrm{d}}$ & $2.55^{\mathrm{d}}$ & $1.44^{\mathrm{c}}$ & $1.43^{\mathrm{b}}$ & $1.13^{\mathrm{c}}$ & $1.49^{\mathrm{b}}$ & $0.19^{\mathrm{cd}}$ & $0.25^{\mathrm{b}}$ \\
\hline 150 & $0.232^{\mathrm{d}}$ & $0.253^{\mathrm{c}}$ & $3.27^{\mathrm{c}}$ & $3.16^{\mathrm{c}}$ & $0.88^{\mathrm{d}}$ & $1.29^{\mathrm{bc}}$ & $1.36^{\mathrm{b}}$ & $1.21^{\mathrm{c}}$ & $0.20^{\mathrm{c}}$ & $0.21^{\mathrm{c}}$ \\
\hline 200 & $0.261^{b}$ & $0.265^{b}$ & $4.55^{\mathrm{b}}$ & $4.74^{\mathrm{b}}$ & $0.84^{\mathrm{d}}$ & $1.31^{\mathrm{bc}}$ & $1.61^{\mathrm{a}}$ & $1.14^{\mathrm{c}}$ & $0.23^{\mathrm{a}}$ & $0.18^{\mathrm{d}}$ \\
\hline 300 & $0.270^{\mathrm{a}}$ & $0.278^{\mathrm{a}}$ & $5.66^{\mathrm{a}}$ & $5.73^{\mathrm{a}}$ & $0.77^{\mathrm{e}}$ & $1.31^{\mathrm{bc}}$ & $1.64^{\mathrm{a}}$ & $1.21^{\mathrm{c}}$ & $0.21^{\mathrm{b}}$ & $0.18^{\mathrm{d}}$ \\
\hline
\end{tabular}


plantlets in the presence of $\mathrm{Na}$ may be attributed to Na-K competition. Growth and $\mathrm{K}$ concentration in gradual exposure treatments declined less than in cases of continuous exposure, or even increased slightly, which may be an indication of the high adaptability of trifoliate orange to high salinity. In addition, it shows that, for salinity tolerance studies, gradual transfer is preferable to continuous exposure.

Calcium and $\mathrm{Mg}$ concentration increased in all saline treatments (Tab. 2). These results are in agreement with those of other researchers experimenting with Carrizo (Poncirus trifoliata $\times$ Citrus sinensis) hybrids and Citrus macrophylla explants (GARCIA-SANCHEZ et al. 2003, PEREZ-Tornero et al. 2009). Calcium concentration in explants presented a lower increase in the treatments with gradual transfer than in those with a continuous exposure to high $\mathrm{NaCl}$ concentration in the nutrient medium. It has been reported that $\mathrm{Mg}$ concentration in plants is diminished, enhanced or not affected by salinity (DIONISIO and ANTONII 1997, Roussos et al. 2007). This discrepancy found in proliferated explants, lacking a root system, could be related to differences in the diffusion rates of mineral nutrients in the culture medium with high $\mathrm{NaCl}$ concentrations (PEREZ-TorNERO et al. 2009).

In all $\mathrm{NaCl}$ treatments, $\mathrm{Mn}$ and $\mathrm{Zn}$ concentrations of explants were significantly reduced by salinity (data not shown). It is possible that the diffusion rate of the above ions decreases with increasing osmotic potential of the medium due to salinity, resulting in lower ion availability.

Finally, to counter increasing external salinity, plant cells must adjust osmotically, either by accumulating ions or by increasing their synthesis of organic solutes such as proline and sugars (FERGUSON and GRATTAN 2005). In the present experiment, proline concentration presented a significant increase in the explants cultured with 200 or $300 \mathrm{mM} \mathrm{NaCl}$ (and with $100 \mathrm{mM} \mathrm{NaCl}$ under continuous exposure) (Tab. 1). Similar results were observed in Citrus macrophylla explants where even at $60 \mathrm{mM} \mathrm{NaCl}$ the proline levels increased significantly, rising in line with the external salt concentration (PEREZ-TORNERO et al. 2009). Accordingly, there was a positive effect of salinity on sugar concentration (except the treatment $300 \mathrm{mM}$ $\mathrm{NaCl}$ in continuous exposure) (Tab. 1). Increased proline and sugar levels were also reported by RocHDI et al. (2003) working with sour orange explants treated with $137 \mathrm{mM}$ $\mathrm{NaCl}$.

In conclusion, the inclusion of $\mathrm{NaCl}$ in the nutrient medium leads to significant alterations in the growth, chemical status and proline and sugar concentrations of trifoliate orange explants.

\section{Acknowledgements}

We would like to thank S. Kouti and V. Tsakiridou for their assistance in chemical analyses.

\section{References}

Chatzissavvidis, C., Veneti, G., Papadakis, I., Therios, I. N., 2008: Effect of $\mathrm{NaCl}$ and $\mathrm{CaCl}_{2}$ on the antioxidant mechanism of leaves and stems of the rootstock CAB-6P (Prunus cerasus L.) under in vitro conditions. Plant Cell Tissue and Organ Culture 95, 37-45.

Dionisio, R. M., ANTONII, C., 1997: Citrus response to salinity: Growth and nutrient uptake. Tree Physiology 17, 141-150. 
FERGUSON, L., GratTAn, S. R., 2005: How salinity damages citrus: osmotic effects and specific ion toxicities. HortTechnology 15, 95-99.

Flowers, T. J., YEO, A. R., 1986: Ion relations of plant under drought and salinity. Australian Journal of Plant Physiology 13, 75-91.

Garcia-Sanchez, F., Carvajal, M., Cerda, A., Martinez, V., 2003: Response of 'Star Ruby' grapefruit on two rootstocks to $\mathrm{NaCl}$ salinity. Journal of Horticultural Science and Biotechnology 78, 859-865.

Ghaleb, W. S., Sawwan, J. S., Akash, M. W., Al-Abdallat, A. M., 2010: In vitro response of two Citrus rootstocks to salt stress. International Journal of Fruit Science 10, 40-53.

Grattan, S. R., Grieve, C. M., 1998: Salinity-mineral nutrient relations in horticultural crops. Scientia Horticulturae 78, 127-157.

Khan, A. A., McNeilly, T., Collins, J. C., 2000: Accumulation of amino acids, proline and carbohydrates in response to aluminum and manganese stress in maize. Journal of Plant Nutrition 23, 1303-1314.

Koo, R. C. J., Anderson, C. A., Steward, I., Tucker, D. P. H., Calvert, D. V., Wutscher, H. K., 1984: Recommended fertilizers and nutritional sprays for citrus. Florida Agricultural Experiment Station Bulletin 536D.

MAas, E. V., 1984: Salt tolerance of plants. In: CHristie, B. R. (ed.), The handbook of plant science in agriculture. CRC Press, Boca Raton, Florida.

Mills, D., Zhang, G., Benzioni, A., 2001: Effect of different salts and of ABA on growth and mineral uptake in jojoba shoots grown in vitro. Journal of Plant Physiology 158, 1031-1039.

Munns, R., James, R. A., LAuChli, A., 2006: Approaches to increasing the salt tolerance of wheat and other cereals. Journal of Experimental Botany 57, 1025-1043.

Murashige T., Skoog F., 1962: A revised medium for rapid growth and bioassays with tobacco tissue cultures. Physiologia Plantarum 15, 473-497.

Perez-Tornero, O., Tallon, C. I., Porras, I., Navarro, J. M., 2009: Physiological and growth changes in micropropagated Citrus macrophylla explants due to salinity. Journal of Plant Physiology 166, 1923-1933.

Rochdi, A., El Yacoubi, H., Rochdi, A. R., 2003: Responses to $\mathrm{NaCl}$ stress of Citrus aurantium, Citrange troyer and Poncirus trifoliata in callus cultures: Assessment of characters for evaluating salt stress responses in citrus rootstocks. Agronomie 23, 643-649.

Roussos, P. A., Gasparatos, D., Tsantili, E., Pontikis, C. A., 2007: Mineral nutrition of jojoba explants in vitro under sodium chloride salinity. Scientia Horticulturae 114, 59-66.

Shibli, R. A., Shatnawi, M. A., Swaidat, I. Q., 2003: Growth, osmotic adjustment, and nutrient acquisition of bitter almond under induced sodium chloride salinity in vitro. Communications in Soil Science and Plant Analysis 34, 1969-1979.

Shiyab, S. M., Shibli, R. A., Mohammad, M. M., 2003: Influence of sodium chloride salt stress on growth and nutrient acquisition of sour orange in vitro. Journal of Plant Nutrition 26, 985-996.

ZHU, J. K., 2001: Plant salt tolerance. Trends in Plant Science 6, 66-71. 